\title{
THE INFLUENCE OF PLANT MULCHES ON THE CONTENT OF PHENOLIC COMPOUNDS IN SOIL AND PRIMARY WEED INFESTATION OF MAIZE
}

\author{
Agnieszka Stokłosa ${ }^{1}$, Tomasz Hura ${ }^{2}$, Ewa Stupnicka-Rodzynkiewicz ${ }^{1}$, \\ Teresa Dąbkowska ${ }^{1}$, Andrzej Lepiarczyk ${ }^{1}$ \\ ${ }^{1}$ Department of Soil Management and Plant Cultivation, University of Agriculture, Al. Mickiewicza 21,31-120 Krakow, \\ e-mail: astoklosa@ar.krakow.pl \\ ${ }^{2}$ The Franciszek Górski Institute of Plant Physiology, Polish Academy of Sciences, Niezapominajek 21, 30-239 Kraków, Poland
}

Received: 15.06 .2008

\section{$\mathrm{S} \mathrm{u} \mathrm{m} \mathrm{m} \mathrm{a} \mathrm{r} \mathrm{y}$}

In growing maize, an increase in the content of phenolic compounds and selected phenolic acids in soil was found after the incorporation of white mustard, buckwheat, spring barley, oats and rye mulches into the soil. The highest content of phenolic compounds in soil was found after oats mulch incorporation (20\% more than in the control soil). The highest content of selected phenolic acids was found for the soil with the oats and rye mulch. Among the phenolic acids investigated, ferulic acid was most commonly found in the soil with the plant mulches. However, two phenolic acids: the protocatechuic and chlorogenic acid, were not detected in any soil samples (neither in the control soil nor in the mulched soil).

At the same time, a decrease in the primary weed infestation level in maize was found in the plots with all the applied plant mulches, especially on the plots with oats, barley and mustard. The plant mulches were more inhibitory against monocotyledonous weeds than dicotyledonous ones.

During high precipitation events and wet weather, a rapid decrease in the content of phenolic compounds in soil and an increase in the primary weed infestation level in maize were observed.

Key words: primary weed infestation, phenolic acids, phenolic compounds, plant mulches, soil

\section{INTRODUCTION}

The use of plant mulches in agriculture becomes more and more popular, especially in organic and in-

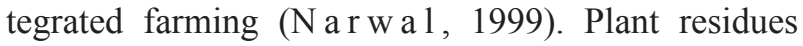
decomposing in soil play a double role: they supply soil with organic matter and also provide a barrier for weed emergence, which is connected with their physical presence in soil and with release of allelochemicals during their decay (In derjit and Keating, 1999). Among allelochemicals, phenolic compounds are most commonly listed ( $\mathrm{M}$ a c i a s et al. 2007).
Plant mulches may be left on soil surface, as cover crops, or may be incorporated with soil ( $\mathrm{Ho}$ c hol et al. 2004; D h i m a et al. 2006). The duration of cover crops residues in soil determines the extent of an effective weed control period ( $\mathrm{B} \mathrm{h} \mathrm{o} \mathrm{w} \mathrm{m} \mathrm{i} \mathrm{k} \mathrm{and}$ I n d e r j i t , 2003). In field conditions, many factors influence the presence and allelopathic potential of residues, like various soil physical, chemical and biological factors (K o b a y a s h i, 2004) and weather conditions (S t u p n i c ka - R o d z y n ki e w i c z et al. 2004). As a consequence, interactions noticed in the controlled conditions may be less visible in the field ( I $\mathrm{n} \mathrm{de} \mathrm{j} \mathrm{j} \mathrm{i}$ and F o y, 2001; I q b a 1 et al. 2003). As an example, Xuan et al. (2005) evaluated allelopathic potential of alfalfa (Medicago sativa L. cv. Rasen) and kava (Piper methysticum L.) after soil amendment by their mulches in the field experiment. A strong inhibitory effect of both alfalfa and kava mulches on barnyardgrass and monochoria growth for up to ten days was stated, but after this period the magnitude of inhibition was drastically reduced. The authors have confirmed that the mulched soil contained high amounts of phenolic compounds which have been recognized by many authors as substances with significant allelopathic potential (We s t o n and D u k e, 2003). On the other hand, phenolic compounds concentration in soil is strongly modified by many physical and chemical factors (I $n$ d e r j i t, 1996). Some role in the magnitude and duration of phytoxicity of individual phenolic acids in soil is played by reversible sorption, which partly protects these substances from microbial degradation $(\mathrm{B} 1 \mathrm{u} \mathrm{m}$, 1998).

H u r a et al. (2006) examined the level of eight selected phenolic acids in 5 crop-plant species: buckwheat (Fagopyrum esculentum Moench.), mustard (Sinapis alba L.), winter rye (Secale cereale L.), spring barley (Hordeum sativum L.) and oats (Avena sativa L.) 
during two vegetative seasons in 2002 and 2003. The authors found significant differences in each phenolic acid content in plants, depending on weather conditions during the growing period of the plants. The plants were arranged from the most to the least abundant in phenolic acids, in the following order: spring barley $>$ oats $>$ buckwheat $>$ white mustard $>$ rye.

In the present paper, three hypotheses are tested: 1) the concentration of phenolic compounds increase in soil after incorporating each of the above mentioned plants as a mulch; 2) primary weed infestation changes after the incorporation of mulches; 3) phenolic compounds from mulches decrease weed emergence and, in consequence - primary weed infestation in maize through an allelopathic interaction.

The study aimed at (1) determining the concentration of phenolic compounds in soil, after incorporating plant mulches into it; and (2) assessing primary weed infestation of maize after the incorporation of plant mulches.

\section{MATERIALS AND METHODS}

The field experiment was conducted at the Experimental Station of the Department of Plant and Soil Cultivation of the University of Agriculture, at Mydlniki near Kraków (Poland), during three successive vegetation seasons 2002-2004. The site was located at $50^{\circ} 5^{\prime} \mathrm{N}, 19^{\circ} 51^{\prime} \mathrm{E}$; mean height $224 \mathrm{~m}$ a.s.1. The experimental brown soil contained $71 \%$ of sand, $18 \%$ of silt and $11 \%$ of clay, $\mathrm{pH} 6.1$. The concentration of basic elements was as follows: $0.11 \% \mathrm{~N}, 7.61 \mathrm{mg}$ P per 100 g, $13.45 \mathrm{mg} \mathrm{K}$ per $100 \mathrm{~g}$.

The two-factorial experiment $\left(1^{\text {st }}\right.$ factor - soil with plant mulch, $2^{\text {nd }}$ factor - technology of mulch incorporation into soil) was set up as a split-plot design, with four replications. The plot size was $12 \mathrm{~m}^{2}$ (4 by $3 \mathrm{~m}$ ). Maize (Zea mays L., cv. Kasia) was grown in the experiment. As a natural source of phenolic compounds, plant mulches of 5 crop-plant species were used: white mustard (Sinapis alba L., cv. Barka), buckwheat (Fagopyrum esculentum Moench., cv. Hruszowska), spring barley (Hordeum sativum L., cv. Klimek), oats (Avena sativa L., cv. Dragon) and winter rye (Secale cereale L., cv. Esprit). Two technologies were applied for mulching plants: I. sowing in early April, before maize planting, and then, after about a month, incorporating the growing plants into soil (by rototiller) at a depth of $10 \mathrm{~cm}$, just before maize planting; II. sowing in the beginning of May in maize interrows and incorporation into soil a month after maize planting. Plots without mulch were used as a control. Details of mulches and soil sampling operations are displayed in Table 1.

In the seasons 2002 and 2004, the total content of phenolic compounds in soil was measured 20 days after incorporation (DAI) of mulches with respect to each technology. Moreover, in 2003 the total content of phenolic compounds in soil and the content of eight individual phenolic acids: chlorogenic, ferulic, $p$-hydroxybenzoic, $p$-coumaric, protocatechuic, salicylic, trans-cinnamic and vanillic, were measured after 10 and 20 DAI with respect to each technology.

Soil preparation and phenolic compounds analysis. On each plot, 3 samples of soil were taken and properly mixed. A sample of $5 \mathrm{~g}$ of air-dried soil was extracted with $10 \mathrm{ml}$ of $80 \%$ ethanol and shaken for 1 hour. The soil extract $(2 \mathrm{ml})$ was centrifuged at $4,000 \mathrm{x} g$ for $15 \mathrm{~min}$. at a temperature of $3^{\circ} \mathrm{C}$. The extract was condensed to $1 \mathrm{ml}$ in a CentriVap Concentrator (LABCONCO, Kansas City, Missouri, USA). For the measurement, $0.5 \mathrm{ml}$ of the extract with 0.5 $\mathrm{ml}$ of water, $0.5 \mathrm{ml}$ of carbonate $(0.25 \%)$ and $0.125 \mathrm{ml}$ of Folin-Ciocalteu (S inglet on and R os si 1965) reagent were taken.

Trans-cinnamic acid, salicylic acid, ferulic acid, chlorogenic acid, $p$-hydroxybenzoic acid, protocatechuic acid, $p$-coumaric acid and vanillic acid were purified with silica gel thin-layer chromatography (TLC, silica gel $60 \mathrm{~F}_{254}$ Merck \& Co., Inc., $0.25 \mathrm{~mm}$ thick). In order to better identify phenolics, a small volume $(2,5 \mu 1)$ containing a known concentration of pure phenolic compounds $\left(5{\mathrm{mg} \times \mathrm{ml}^{-1}}^{-1}\right.$ was added to the extract. The mixture of benzene, acetic acid and $\mathrm{MeOH}(45: 8: 4$ $\mathrm{v} / \mathrm{v} / \mathrm{v}$ ) was used as developing solvent. The phenolics were located on the TLC plates as spots under UV radiation. The phenolic compounds from silica gel were scraped off and eluted with $3 \mathrm{ml}$ of $80 \%$ aqueous ethanol. The concentration of phenolics was determined using a spectrophotometer (Perkin Elmer, Norwalk, CT, USA). Absorbance was measured at $290 \mathrm{~nm}$. The phenolics concentration was expressed as $\mu \mathrm{g} \times \mathrm{g}^{-1} \mathrm{DW}$ (dry weight of soil). The analysis of individual phenolic compounds was performed in 3 replications.

Maize primary weed infestation assessment. Weed seedlings were counted 3 weeks after mulch incorporation into the soil for technology I and 4 weeks after mulch incorporation for technology II. Weeds were counted on an area of $0.25 \mathrm{~m}^{2}(10 \times 250 \mathrm{~cm})$ in 2 replications, on each plot (a total sum of 8 replications for each mulch with respect to each technology). Weed counting was conducted on the following dates: for technology I - 7 June 2002, 30 May 2003, 27 May 2004; for technology II - 26 June 2002, 26 June 2003, 28 June 2004.

Statistical analysis. Analysis of variance (ANOVA), with use of STATISTICA PL 7.1 (StatSoft, 2005), was performed for the phenolic concentration in soil, by using a two-factorial approach (soil with each type of plant mulch $\mathrm{x}$ technology). One factorial ANOVA was performed for weed density analysis 
(each type of mulch). Common logarithmic transformation of data was performed, when variance was not homogenous (based on Levene's test). Differences between means were found to be significant at $\mathrm{p} \leq 0.05$ level, by Tukey's test.

Weather conditions. Decade rainfall data and mean decade temperatures during the months of April to June 2002-2004 were combined and presented in values of Sielianinov's hydrothermic coefficient $(K)$, according to estimation: $K=\frac{P}{\Sigma(T p \cdot 0.1)}$, where $P$ is the sum of decade rainfall in $\mathrm{mm}$ and $\Sigma(T p \times 0.1)$ is the sum of decade temperatures in ${ }^{\circ} \mathrm{C}$. Ranges of the $K$ coefficient: $<0.3$ catastrophic drought, 0.3-0.5 drought, 0.51.0 humidity below balance, 1.0-2.0 sufficient amount of water, $>2.0$ excess of water $(\mathrm{Ozolinčius} \mathrm{and}$ Stakènas, 2001; Ostrowska et al. 2007).

A large dispersion in $K$ values was observed between the months of April, May and June during the 2002-2004 seasons (Fig. 1). Generally, more wet decades were noted during 2002 and 2003, with the extremely wet first decade of April in $2003(K=23.6)$. The 2004 season was rather dry, with drought observed during the $2^{\text {nd }}$ decade of April and the $3^{\text {rd }}$ decade of June (Fig. 1).

\section{RESULTS}

The amount of biomass introduced into the soil was unequal and depended on both technology and plant species. On average, during the three vegetative seasons, all plants accumulated less biomass in tech- nology I: buckwheat ca. $10 \mathrm{~g}$ of dry weight (DW) $\times \mathrm{m}^{-2}$,

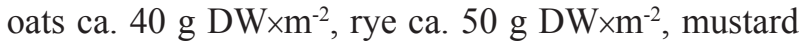
and barley ca. $60 \mathrm{~g} \mathrm{DW} \times \mathrm{m}^{-2}$; in technology II: buck-

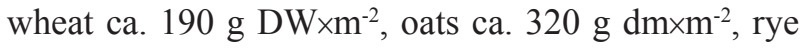

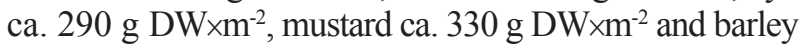
ca. $400 \mathrm{~g} \mathrm{DW} \times \mathrm{m}^{-2}$.

\section{in soil}

Total concentration of phenolic compounds

The level of phenolic compounds in soil was significantly influenced by donor species $(\mathrm{p}=0.05)$ (Fig. 2). Among all the mulches tested, the highest content of phenolic compounds in soil was found after oats incorporation ( $20 \%$ more than in control soil), the lowest after buckwheat incorporation ( $6 \%$ less than in the control soil). The total content of phenolic compounds was also significantly influenced by the vegetative season $(p<0.0000)$. A significantly lower level of phenolic compounds in soil was found in 2003, when during April and May there was an extremely high level of rainfall (Fig. 1). In this season, compared to 2002 and 2004, the level of phenolic compounds in the soil after the incorporation of white mustard, buckwheat, barley and rye mulches into it was significantly lower (Fig. 2).

The type of technology for mulch incorporation into soil was not significantly different $(p=0.5)$; the mean content of phenolic compounds for technology I was: $0.48 \mu{\mathrm{g} \times \mathrm{g}^{-1}}$, and for technology II. $0.49 \mu \mathrm{g} \times \mathrm{g}^{-1}$. The content of phenolic compounds in soil was not significantly affected by the interaction of technology and donor species $(\mathrm{p}=0.9)$.

Table 1

Crop and mulch management and details of soil sample collection.

\begin{tabular}{|c|c|c|c|}
\hline Specification & 2002 & 2003 & 2004 \\
\hline \multicolumn{4}{|l|}{ Dates of plant mulches sowing in technology I: } \\
\hline oats, spring barley, rye, white mustard & 14 March & 31 March & 1 April \\
\hline buckwheat & 12 April & 15 April & 14 April \\
\hline Dates of mulch incorporation with soil, technology I & 6 May & 6 May & 6 May \\
\hline Dates of maize sowing & 6 May & 6 May & 6 May \\
\hline Dates of plant mulches sowing in technology II & 7 May & 7 May & 7 May \\
\hline Dates of soil sample collection for technology I: 10 DAI* & & 16 May & \\
\hline $20 \mathrm{DAI}$ & 26 May & 26 May & 26 May \\
\hline Dates of mulch incorporation with soil, technology II & 5 June & 6 June & 7 June \\
\hline Dates of soil sample collection for technology II: 10 DAI & & 16 June & \\
\hline $20 \mathrm{DAI}$ & 26 June & 26 June & 26 June \\
\hline
\end{tabular}

*DAI - days after incorporation 


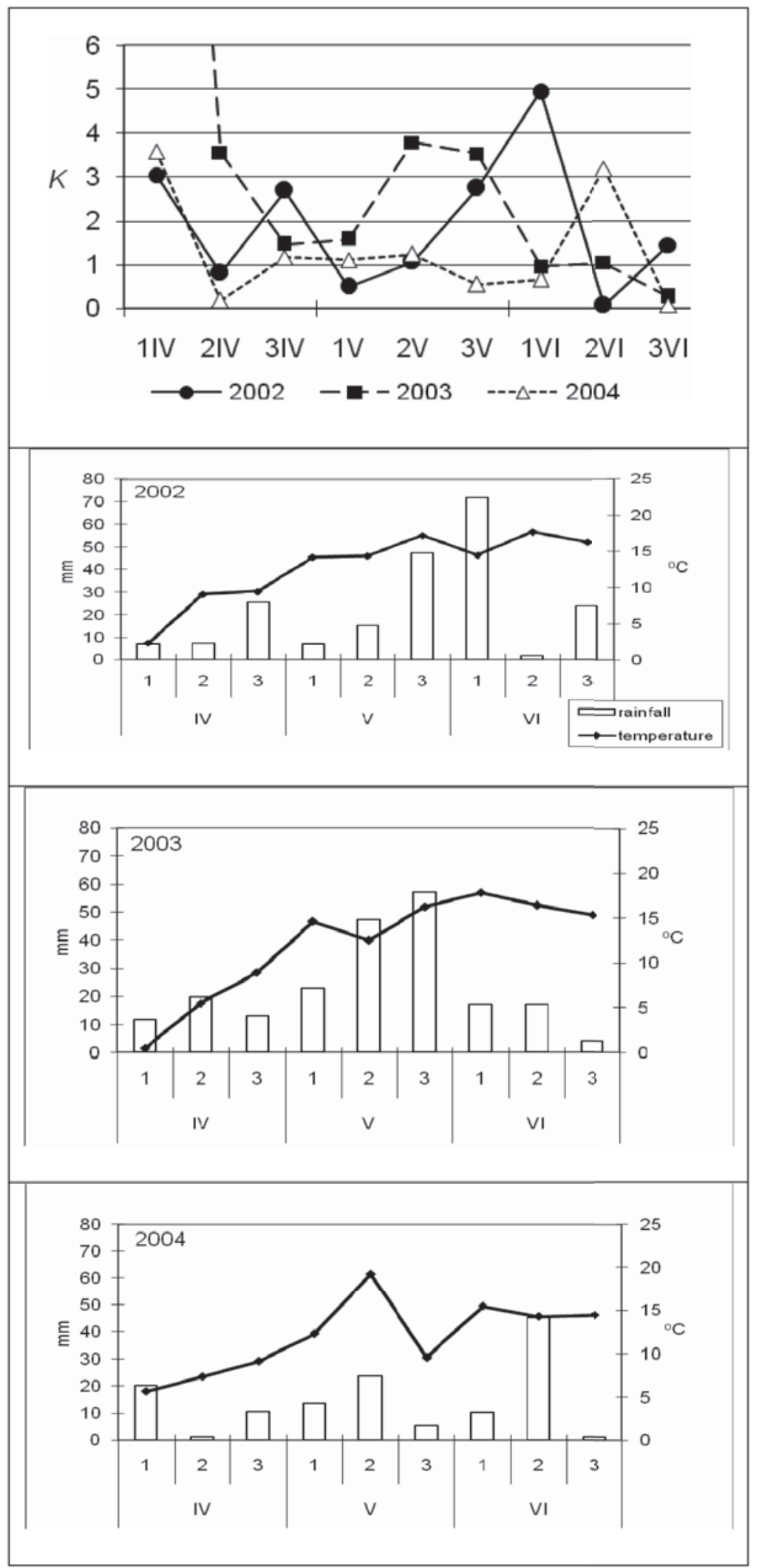

Fig. 1. Coefficient $\mathrm{K}$ values for hydrothermal conditions, total rainfall $(\mathrm{mm})$ and average temperature $\left({ }^{\circ} \mathrm{C}\right)$ in decades $(1-3)$ of April (IV) to June (VI) 2002-2004. 

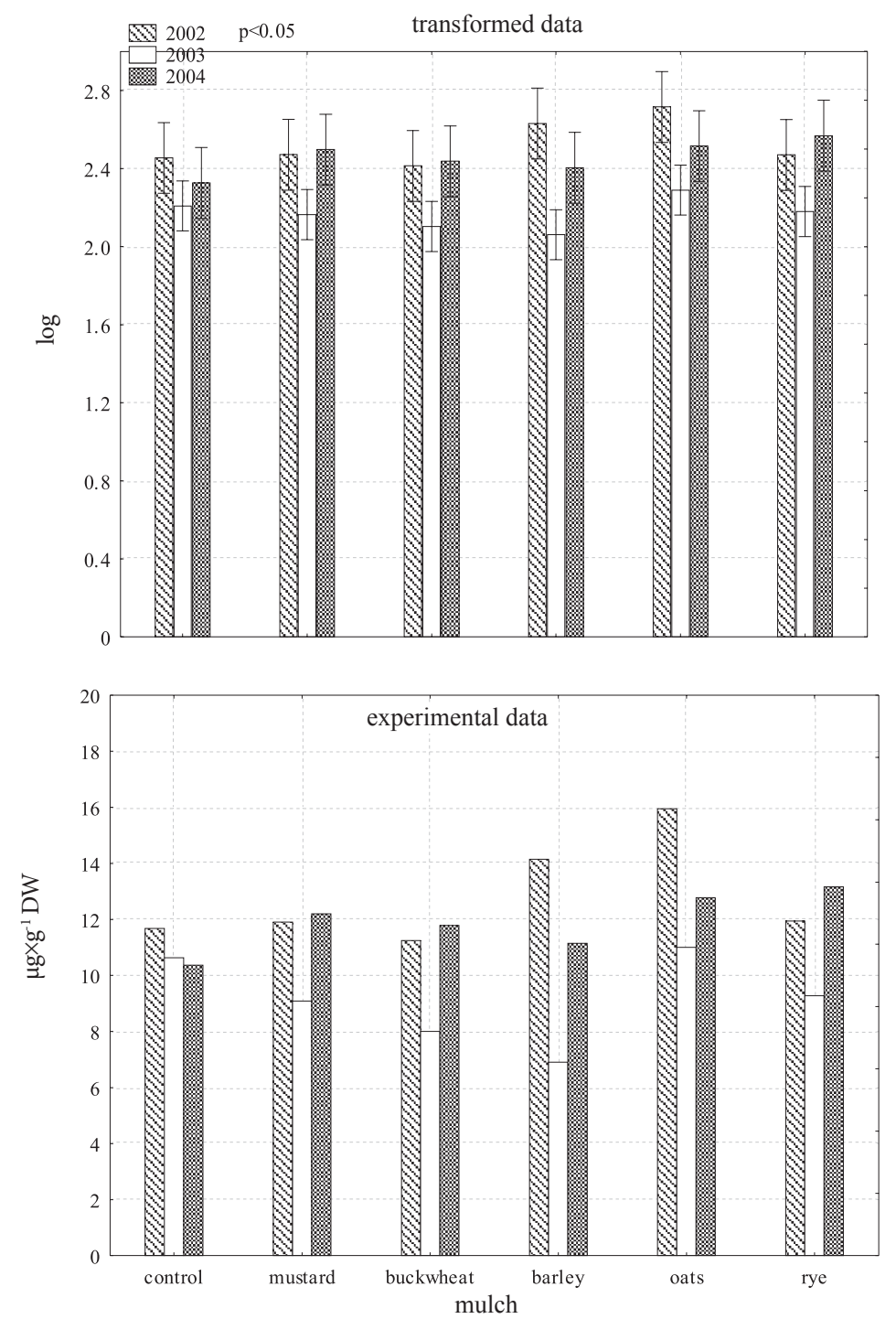

Fig. 2. Mean content of phenolic compounds in soil ( $\mu \mathrm{g} \times \mathrm{g}^{-1}$, logarithm transformed and experimental data) for years 2002-2004, irrespective of technology. Bars correspond to $95 \%$ confidence interval.

In the 2002 growing season, a significantly higher level of phenolic compounds in the soil was found 20 DAI of oats and barley mulches, sown in technology I (Fig. 3). The amount of phenolics in the soil with oats was on average $20.24 \mu{\mathrm{g} \times \mathrm{g}^{-1}}^{-1}$ and with

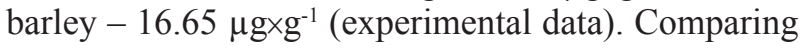
to the control, these concentrations were higher by $64 \%$ and $35 \%$ for these mulch, respectively. For the other mulches, the phenolics concentration in soil $20 \mathrm{DAI}$ was similar as for the control. In technology II, the amount of phenolics in soil 20 DAI was similar to that in the control. Moreover, the level of phenolics in the soil with incorporated barley or oats was significantly lower, comparing to that in technology I, by $30 \%$ and $40 \%$, respectively. In 2002 a higher level of rainfall occurred during the decay of the mulches in technology II, especially during the first decade of June which was extremely wet (Fig. 1).
In the 2003 growing season (Fig. 4), the phenolics concentration in soil measured 20 DAI differed significantly between technology I and II. In technology I, comparing to the control, a significantly lower amount of phenolics in soil was found after the incorporation of barley (by 58\%) and buckwheat (by 52\%) mulches. The content of phenolics in soil found after the incorporation of mustard, oats and rye mulches was similar to that in the control. In technology II, the content of phenolics in soil 20 DAI was similar for all the types of mulches and

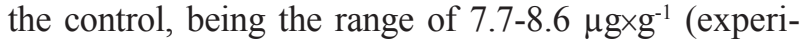
mental data). This lower level of phenolic compounds in soil in technology I may be caused by wet weather occurring in the 2003 season during the first and second decades of May. On the other hand, the weather pattern during the decay of the mulches in technology II was optimal (for the first and second decade of June) and dry for the third decade of June (Fig. 1). 

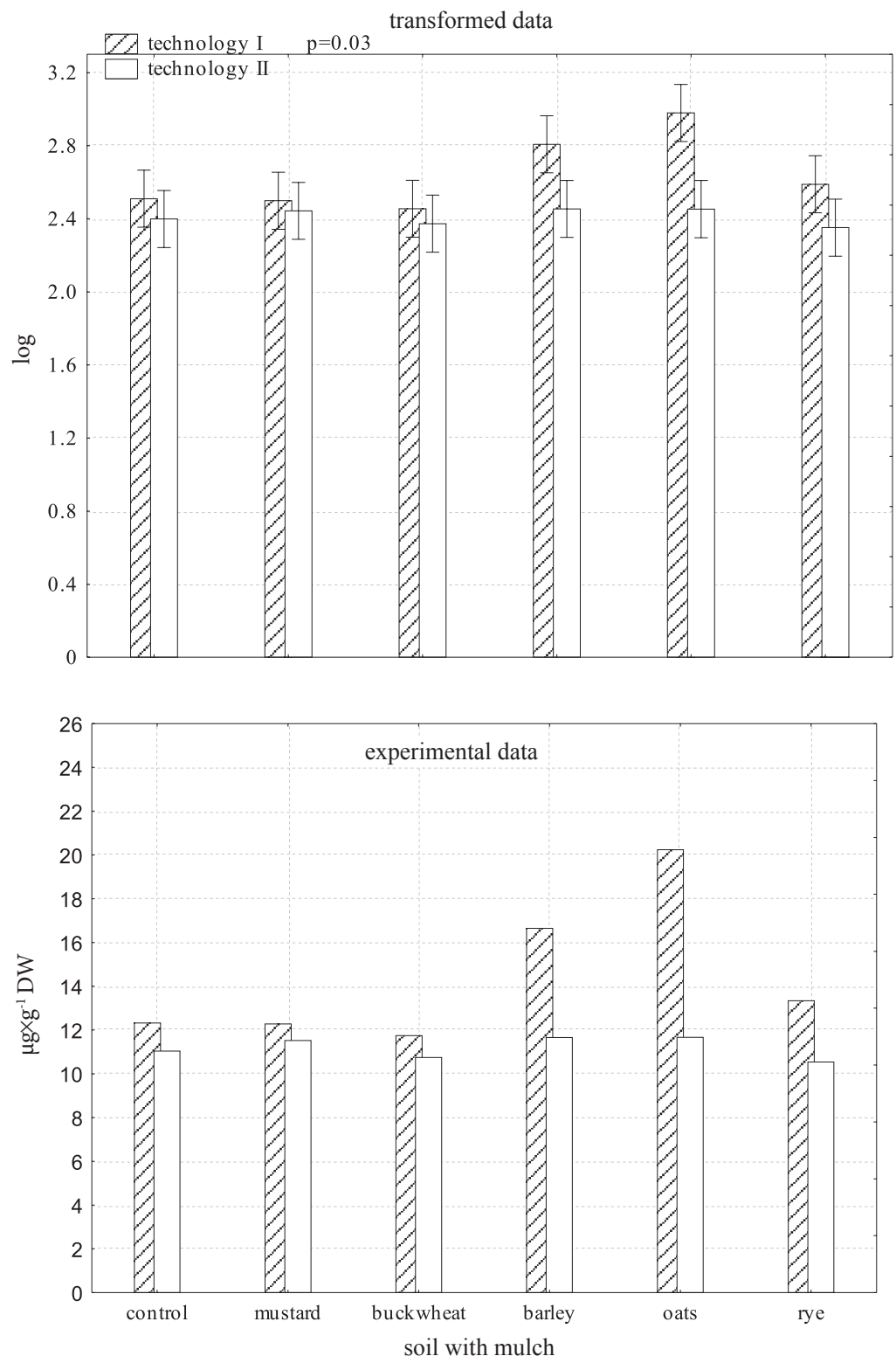

Fig. 3. Mean content of phenolic compounds in soil $\left(\mu \mathrm{g} \times \mathrm{g}^{-1}\right.$, logarithm transformed and experimental data) in technology I and II 20 DAI during the 2002 vegetative season. Bars correspond to $95 \%$ confidence interval.

In the 2004 growing season, the amounts of phenolic compounds in the mulched soil found 20 DAI were similar to that in the control (Fig. 5), in the range

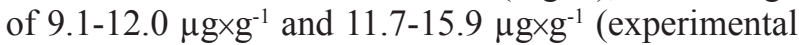
data) for technology I and II, respectively.

The total content of phenolics in soil for each technology was measured twice in the 2003 vegetative season: 10 and 20 DAI (Fig. 6). In technology I, 10 DAI, the phenolics concentration in soil was similar to that in the control soil and the mulched soil. After the next 10 days (20 DAI), the content of phenolics in soil significantly decreased under the buckwheat and barley mulches, comparing to $10 \mathrm{DAI}$, by about $40 \%$ and $50 \%$, respectively. The amount of phenolic com- pounds found in the control soil and the soil with the mustard, oats and rye mulches remained at the same level after 10 and 20 DAI (Fig. 6). Changes in the phenolic compounds content in the soil found after 10 and 20 DAI were not significant in technology II (Fig. 6). in soil

The concentration of selected phenolic acids

The concentration of selected phenolic acids in soil was measured in the 2003 vegetative season. No chlorogenic and protocatechuic acids in the control soil and the mulched soils were found, either in technology I or II. Comparing to the control soil, the soil with the incorporated mulches in technology I contained a higher level of phenolic acids (Fig. 7). In the soil 

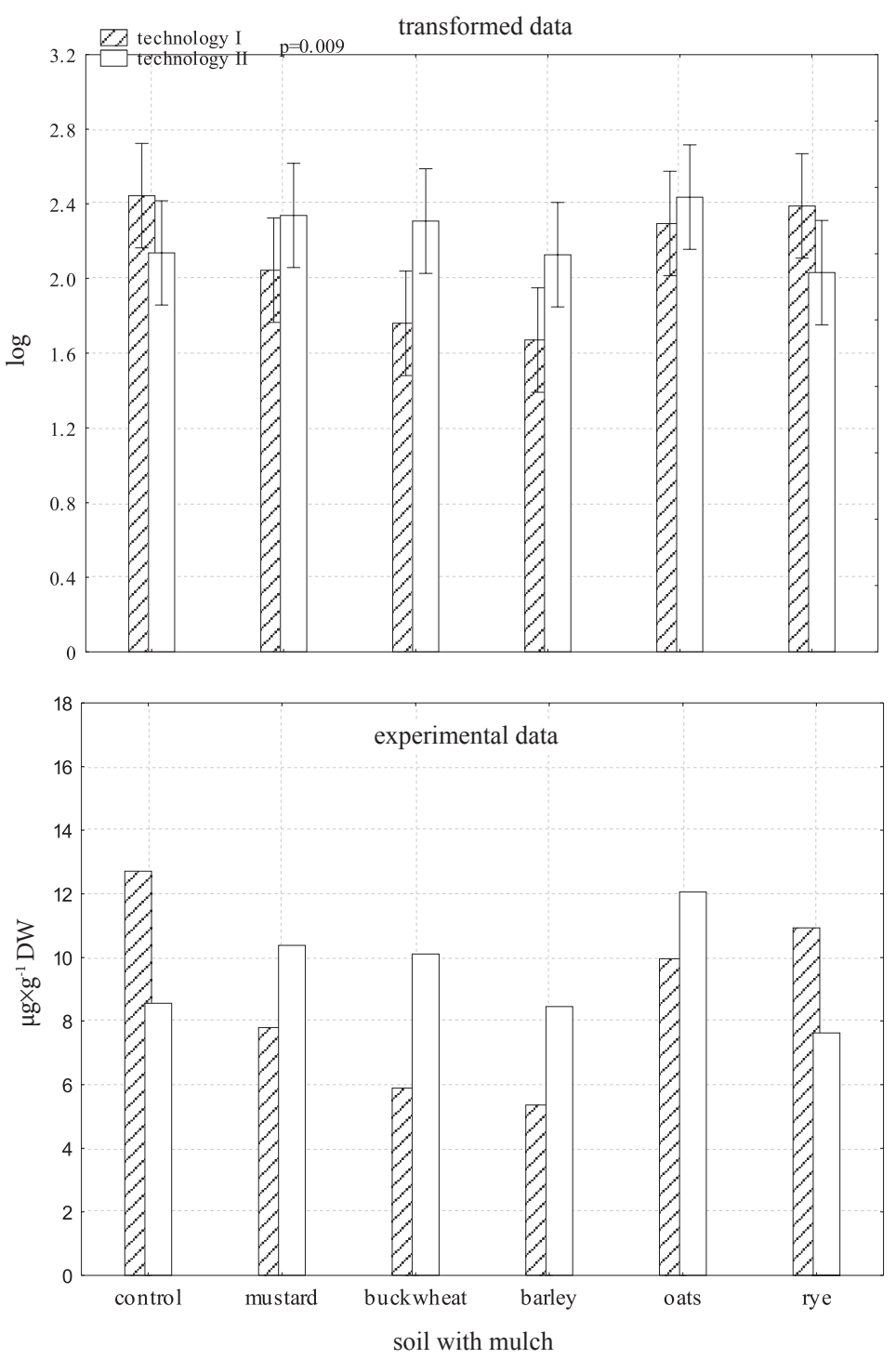

Fig. 4. Mean content of phenolic compounds in soil $\left(\mu \mathrm{g} \times \mathrm{g}^{-1}\right.$, logarithm transformed and experimental data) technology I and II 20 DAI during the 2003 vegetative season. Bars correspond to $95 \%$ confidence interval.

without mulches, a low concentration of ferulic, salicylic and vanillic acids occurred (Fig. 7 a). The control soil contained a small content of $p$-hydroxybenzoic acid. In both, 10 and 20 DAI, the measured level of phenolic acids in the control soil was similar.

The soil with the mustard mulch (Fig. 7 b) incorporated in technology I 10 DAI contained high levels of ferulic, trans-cinnamic and vanillic acids, compared to the control soil. The content of ferulic acid 20 DAI was twice as high as in the control soil. The content of vanillic acid in the soil with the mustard mulch drastically decreased 20 DAI, comparing to 10 DAI (by about $55 \%$ ), while the content of other phenolic acids was similar to that in the control soil. Comparing to the control and the soil with the mustard mulch, the content of phenolic acids in the soil with the buckwheat mulch was high, especially for salicylic acid 20 DAI
(Fig. 7 c). In the case of $p$-hydroxybenzoic acid, a high decrease of its concentration in soil (by 75\%) was 20 DAI, compared to its concentration $10 \mathrm{DAI}$ (from 0.75

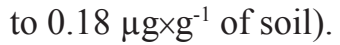

Among the soils incorporated with each of three cereal mulches, the soil with the oats and rye mulches contained higher levels of phenolic acids, comparing to the soil with the barley mulch. The soil with the barley mulch contained higher amounts of ferulic and vanillic acids and small amounts of $p$-coumaric acid 20 DAI (Fig. 7 d). The soil with the oats mulch (Fig. 7 e) contained high amounts of salicylic acid. The content of trans-cinnamic acid decreased by about $60 \%$ and the content of vanillic acid increased almost three times

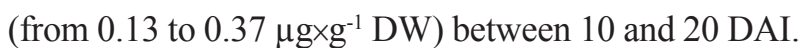
As for the soil with the rye mulch incorporated (Fig. 7 f), an over twice higher level of ferulic acid content was 

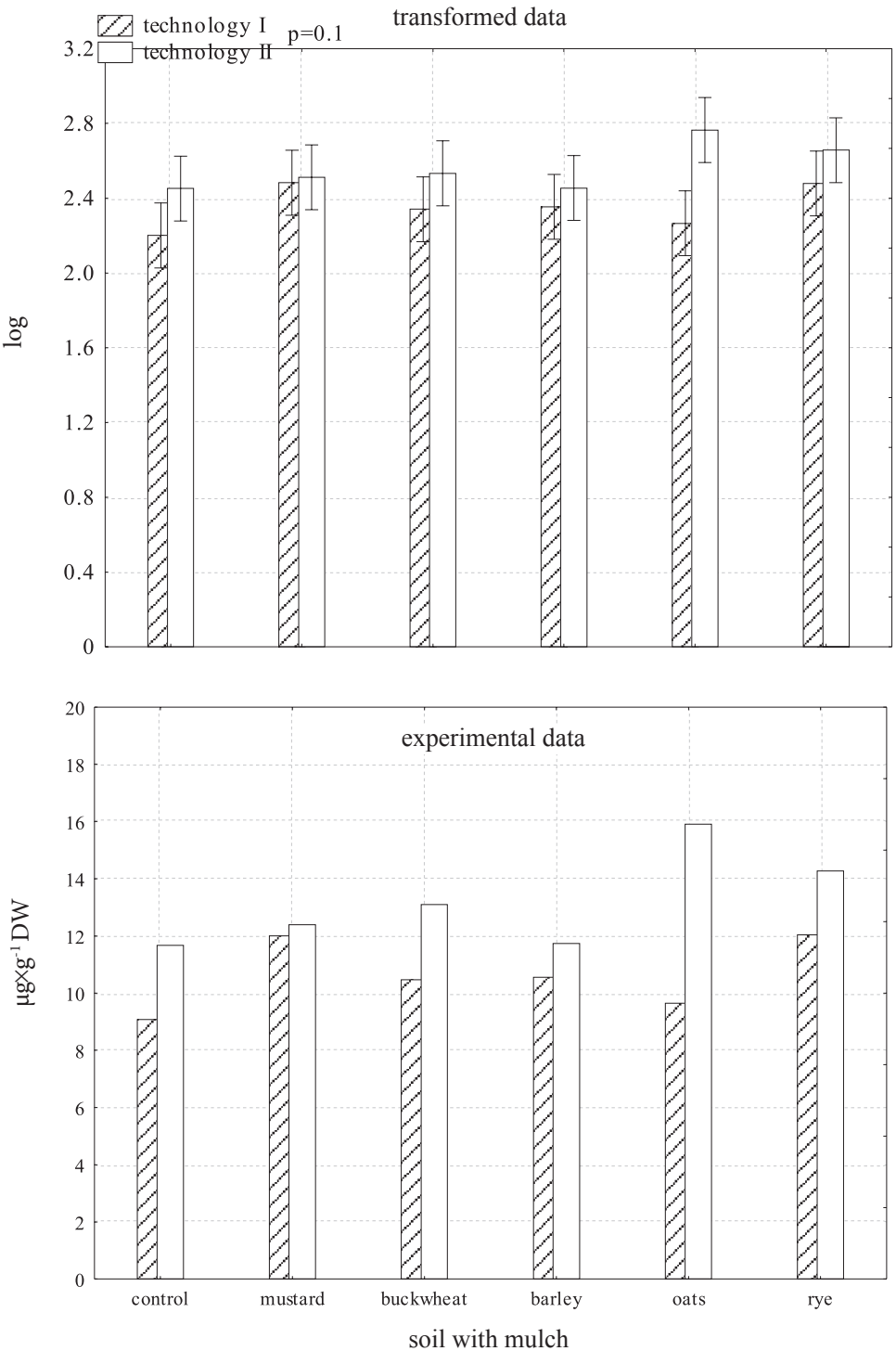

Fig. 5. Mean content of phenolic compounds in soil $\left(\mu \mathrm{g} \times \mathrm{g}^{-1}\right.$, logarithm transformed and experimental data) in technology I and II, 20 DAI during the 2004 vegetative season. Bars correspond to $95 \%$ confidence interval.

found 20 DAI, comparing to 10 DAI. Moreover, high levels of $p$-coumaric and salicylic acids 20 DAI were

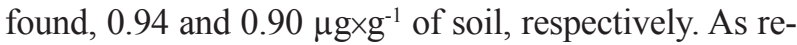
gards the trans-cinnamic acid, an almost 7 times lower level was found 20 DAI compared to 10 DAI.

In II technology, the mulched soils contained higher amounts of ferulic and vanillic acids, comparing to that in the control soil (Fig. 8). The control soil measured in technology II contained similar amounts of phenolic acids as in technology I, except for the vanillic acid which was not found (Fig. 8 a).

The content of phenolic acids in the soil with the incorporated mustard mulch (Fig. 8 b) 20 DAI was similar to that in technology I, except for the transcinnamic acid whose concentration was over 3 times higher. Moreover, 20 DAI the vanillic acid occurred in the soil with the mustard mulch. The soil with incorporated the buckwheat mulch (Fig. $8 \mathrm{c}$ ) 10 DAI contained high amounts of ferulic and $p$-coumaric acids, but after the next 10 days (20 DAI) the concentration of these acids decreased. On the other hand, the concentration of trans-cinnamic acid increased markedly (Fig. 8 c).

In technology II, the soil with the barley mulch (Fig. 8d) contained high amounts of ferulic acid 20 DAI and $p$-coumaric acid 10 DAI. In the soil with the oats mulch (Fig. 8 e), the concentration of ferulic acid 10 DAI was almost twice as high as in technology I, but 20 DAI its concentration decreased by about $50 \%$. The concentration of $p$-hydroxybenzoic and vanillic acids 20 DAI was similar in both technology I and II. However, in technology II 20 DAI a high amount of trans-cinnamic acid was found in the soil with the oats mulch and a significant increase 

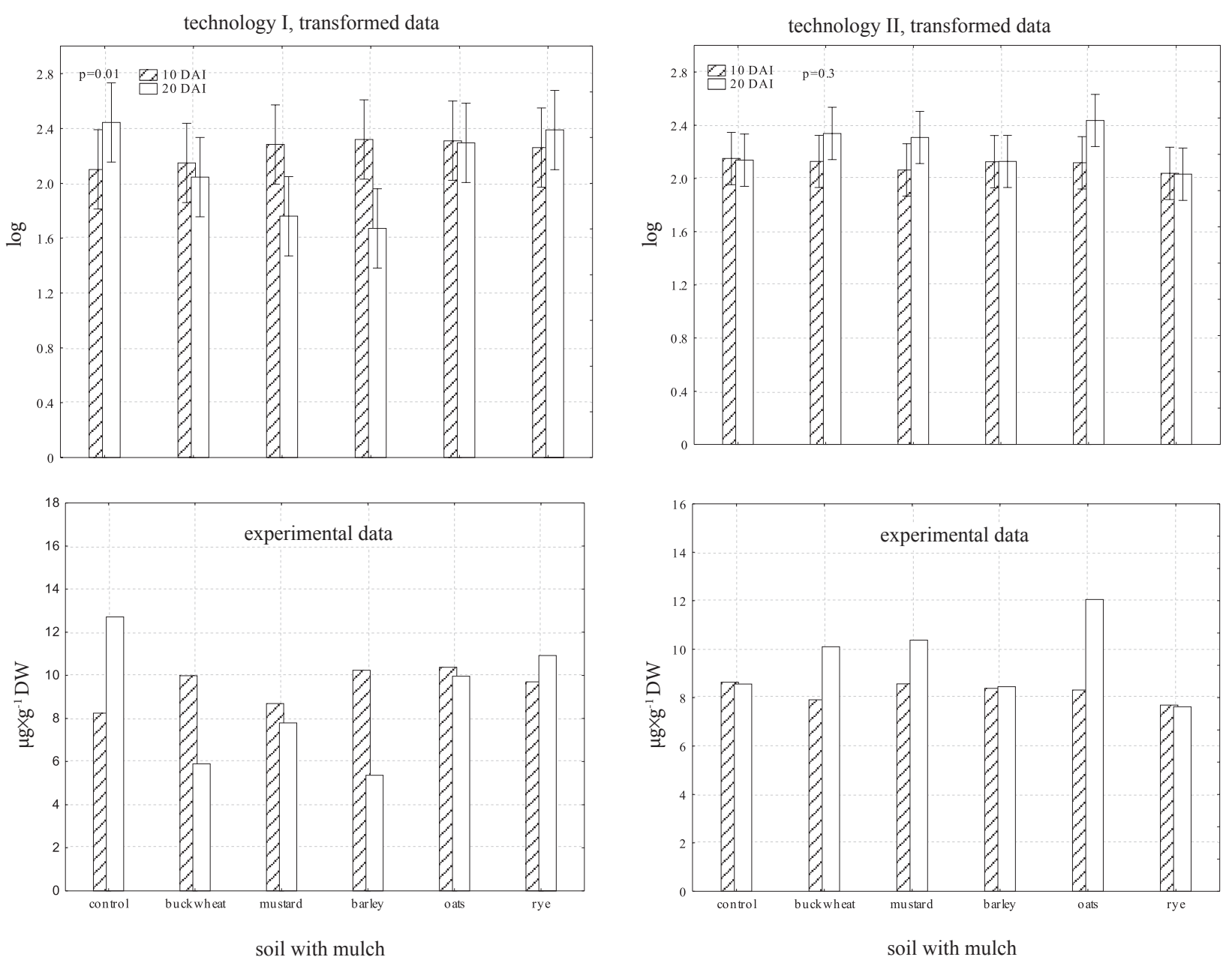

Fig. 6. Mean content of phenolic compounds in soil $\left(\mu \mathrm{g} \times \mathrm{g}^{-1}\right.$, logarithm transformed and experimental data) in technology I and II after 10 and 20 DAI of mulches during the 2003 season. Bars correspond to $95 \%$ confidence interval.

of salicylic acid (form $0.18 \mu{\mathrm{g} \times \mathrm{g}^{-1}}^{-1} \mathrm{DW} 10 \mathrm{DAI}$ to 0.80 $\left.\mu{\mathrm{g} \times \mathrm{g}^{-1}}^{-1} \mathrm{DW} 20 \mathrm{DAI}\right)$ was observed. The concentration of phenolic acids in the soil with the rye mulch 20 DAI was higher, compared to technology I (Fig. $8 \mathrm{f}$ ). The content of ferulic acid in the soil with the rye mulch 20 DAI was similar to that in technology I and the highest, comparing to its concentration in other soils in technology II. Among the phenolic acids tested, this soil contained the lowest concentration of salicylic acid $\left(0.37\right.$ and $0.32 \mu{\mathrm{g} \times \mathrm{g}^{-1}}^{-1}$ soil in technology I and II, respectively).

\section{infestation}

The influence of mulches on primary weed

In the 2002 season, the overall weediness of the plots was similar both for the control and the plots with mulches, both in technology I and II (Tab. 2). The number of weeds on the control plots in 2002 was very low, comparing to that in the control plots in the 2003 and 2004 seasons.

The average weed infestation of the maize plots was lower on the plots with the incorporated mulches in technology II, comparing to technology I (Tab. 2). Generally, the mulches used in the experiment were more inhibitory against monocotyledonous, comparing to dicotyledonous weeds (Tab. 2).

On average, the mustard mulch inhibited $54 \%$, buckwheat $55 \%$, oats $57 \%$, barley $55 \%$ and rye $50 \%$ of monocotyledonous weeds, comparing to the control. As regards dicotyledonous weeds, they were inhibited by mulches in $49 \%, 29 \%, 49 \%, 44 \%$ and $55 \%$, respectively (Tab. 2).

The strongest inhibitory effect of mulches on weed infestation was found in the 2003 season in technology II (Tab. 2). In this technology, the number of monocotyledonous and dicotyledonous weeds was lower comparing to that in the control, by about $80 \%$ and $90-95 \%$, respectively (Tab. 2). A visible decrease in weed density was also observed after the use of mulch in the 2004 season.

On the contrary, during the 2002 season, in technology I an increase in the number of dicotyledonous 

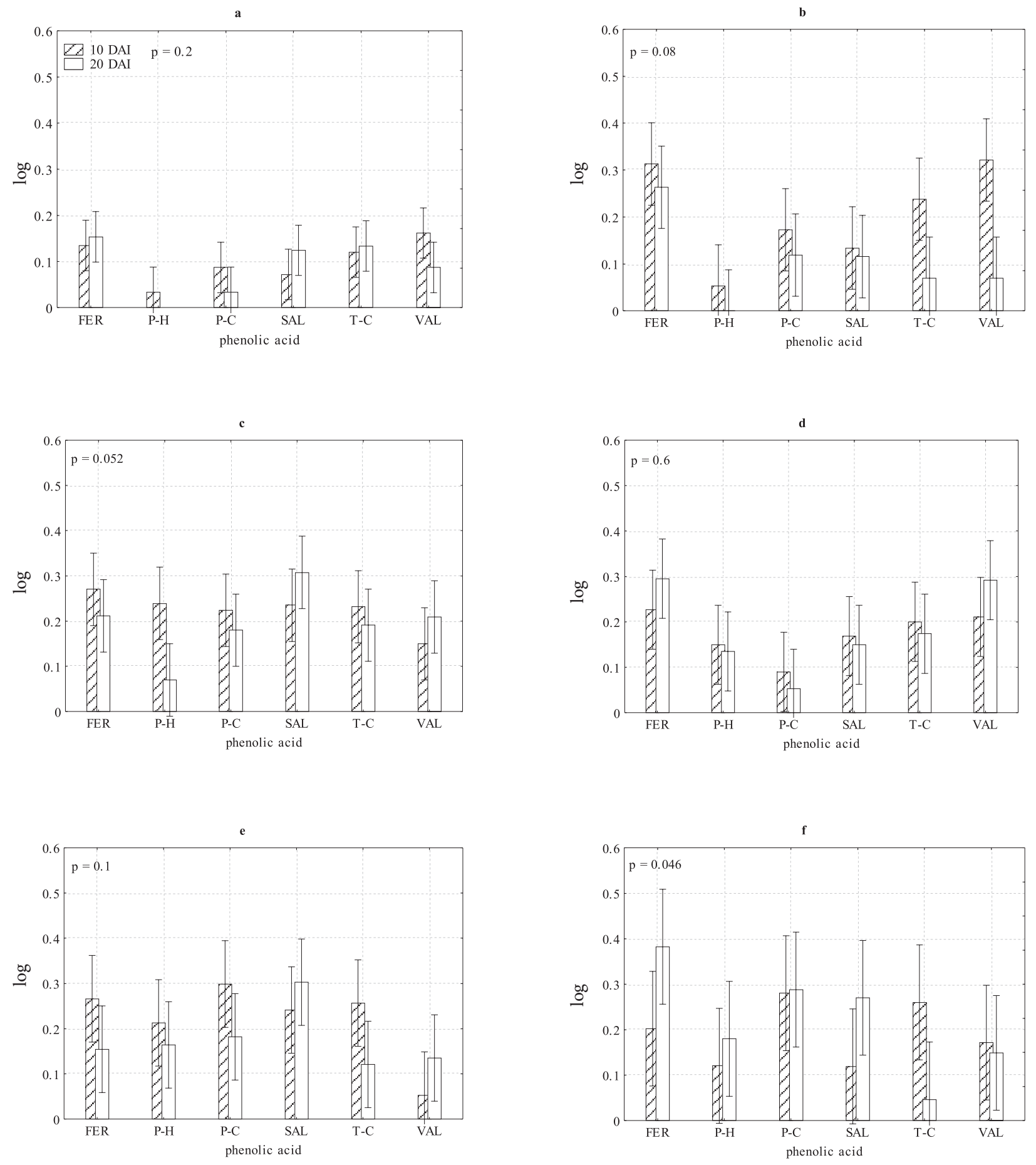

Fig. 7. Composition of selected phenolic acids in the control soil and soils with mulches incorporated in technology I, 10 DAI and 20 DAI $\left(\mu{\mathrm{g} \times \mathrm{g}^{-1}}^{-1}\right.$ logarithm transformed data): a - control, $\mathrm{b}$ - soil with mustard mulch, $\mathrm{c}$ - soil with buckwheat mulch, $\mathrm{d}$ - soil with barley mulch, $\mathrm{e}-$ soil with oats mulch, $\mathrm{f}$ - soil with rye mulch. Bars correspond to $95 \%$ confidence interval. Phenolic acids: FER - ferulic, P-H - p-hydroxybenzoic, P-C - p-coumaric, SAL - salicylic, T-C - trans-cinnamic, VAL - vanillic. 

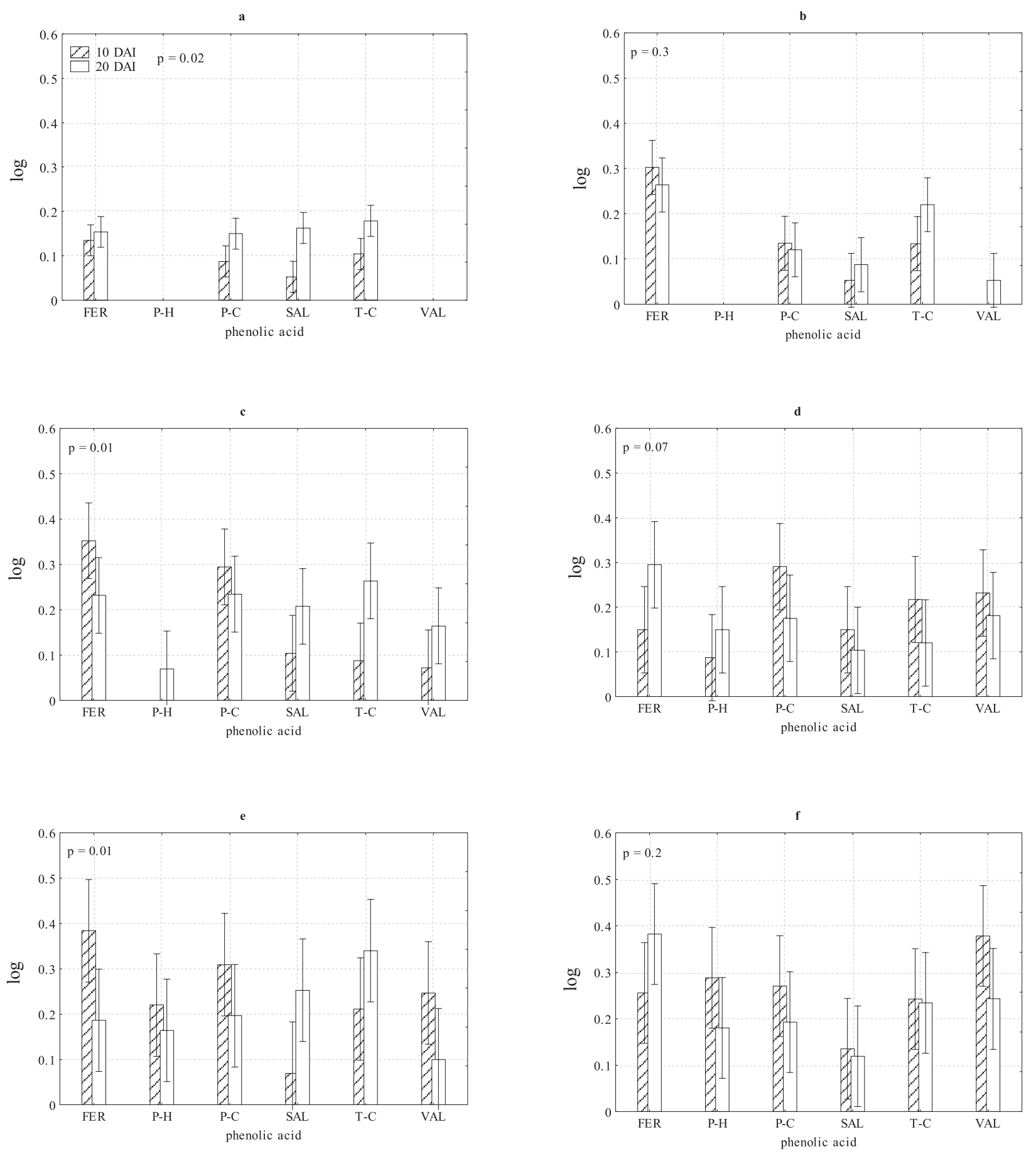

Fig. 8. Composition of selected phenolic acids in the control soil and soils with mulches incorporated in technology II, 10 DAI

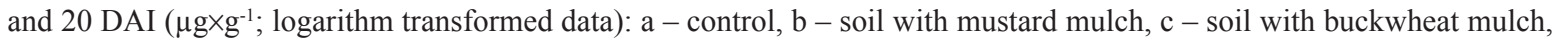
$\mathrm{d}$ - soil with barley mulch, e - soil with oats mulch, $\mathrm{f}$ - soil with rye mulch. Bars correspond to $95 \%$ interval.

Phenolic acids: FER - ferulic, $\mathrm{P}-\mathrm{H}$ - p-hydroxybenzoic, $\mathrm{P}-\mathrm{C}-p$-coumaric, $\mathrm{SAL}$ - salicylic, T-C - trans-cinnamic, VAL - vanillic. 


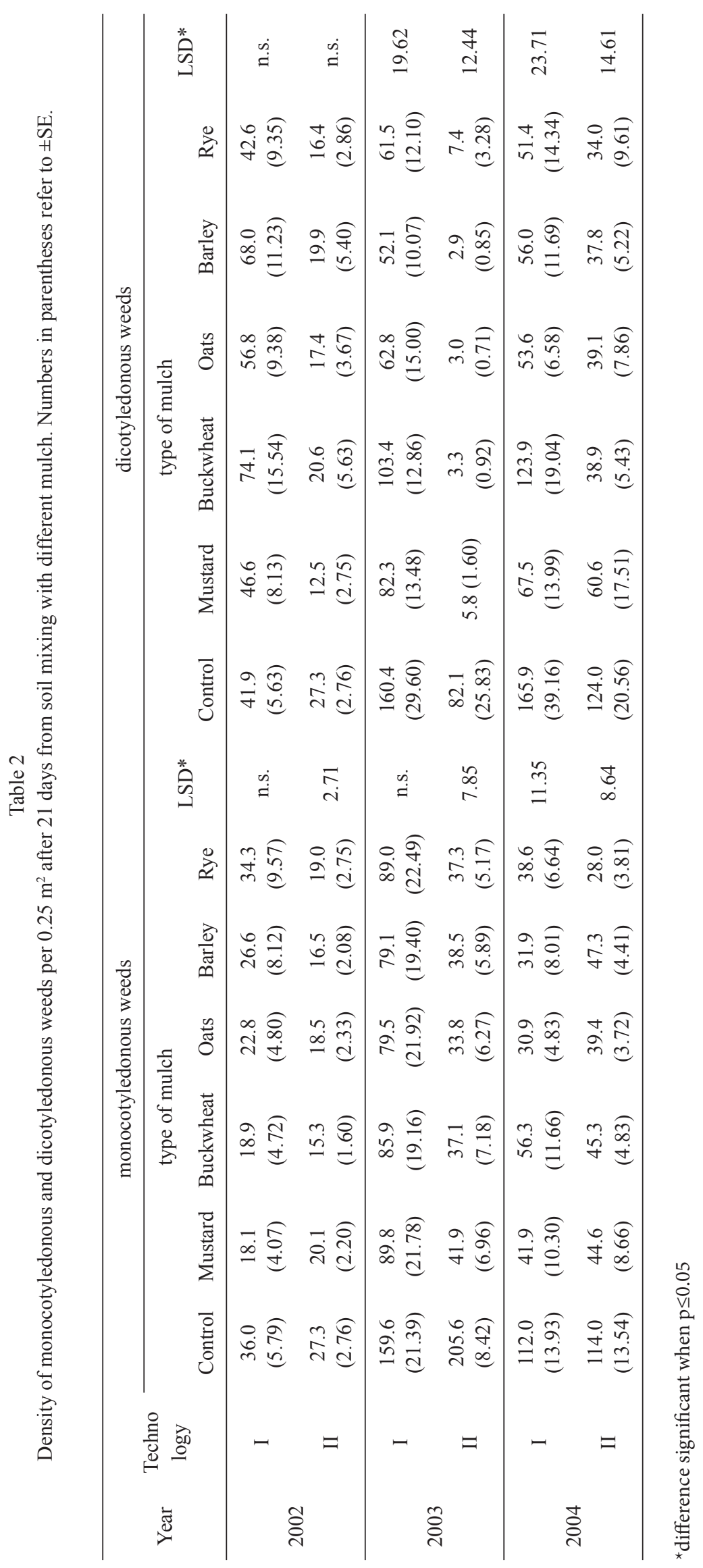


weeds was found, comparing to the control, particularly on the plots with the incorporated buckwheat and barley mulches, by about $80 \%$ and $60 \%$, respectively (Tab. 2). However, the number of monocotyledonous weeds decreased, comparing to the control. The most inhibitory was the mustard mulch (a reduction in weed number by about $50 \%$ ) and the least inhibitory - the rye mulch (a reduction in weed number by about $5 \%$ ) (Tab. 2).

\section{DISCUSSION}

All the plant species used in this experiment as the mulches contained high amounts of phenolic compounds in their tissues, according to $\mathrm{Hura}$ et al. (2006). Nevertheless, in the presented results the amounts of phenolic compounds found in the soil 20 DAI of each mulch were mostly very similar to those in the control soil. Only the soil with the oats and barley mulches incorporated in technology I in 2002 and the soil with the oats mulch incorporated in technology II in 2004 contained higher amounts of phenolic compounds. This indicates strong degradation of phenolics due to the presence of mulches in the soil. Moreover, the time of degradation was shorter than 10 days, as in the 2003 vegetative season. The amounts of phenolic compounds in the soil after this time were the same as in the control soil. The higher rate of phenolics degradation was observed for technology I in 2003, with higher precipitation levels in the second and third decade of May. S o u to et al. (2000) found almost total disappearance of phenolic compounds in spruce forest humus after 6 days of incubation, due to increased degradation by microbes. However, X u a n et al. (2005) detected phenolic acids in the soil with alfalfa or kava mulches even 50 DAI. According to Kefeli et al. (2003), the excretion of phenolics from living maize roots could have additional effect on the phenolic compounds content in soil. A similar phenomenon was observed by $\mathrm{Wu}$ et al. (2000) for wheat roots. Also reversible sorption, which partly protects these substances from microbial degradation, plays a role in the changeable in time level of phenolics in soil (B $1 \mathrm{u} \mathrm{m}$, 1998).

The soil with the incorporated mulches contained a higher level of some phenolic acids, comparing to the control soil. Many of these are putative allelochemicals (I q b a l et al. 2003). The soil with the cereal mulches contained high amounts of $p$-coumaric and ferulic acids, which is consistent with the findings of Whitehead et al. (1982). S z ajdak and Ż y c ińs k a - B ało n i a k (1994), in soil under continuous rye cultivation, found a high content of vanillic acid and the smallest content of $p$-coumaric acid. Ch o u and Patrick (1976) among others identified vanilic, ferulic, $p$-coumaric, $p$-hydroxybenzoic and salicylic acids in decomposing rye residues, which exhibited phytotoxicity to lettuce seeds germination.

The amounts of phenolic acids were very changeable in the soil between 10 DAI and 20 DAI in each of technologies. According to S o u to et al. (1998), soil microorganisms are responsible for a significant decrease of $p$-hydroxybenzoic and vanillic acids and the formation of ferulic and $p$-coumaric acids, which are products of lignin degradation in soil. O h n o (2001) states that phenolic acids are very reactive in soil and degrade not only by increased activity of microbes, but also through oxidation, what limits their allelopathic potential. This author found that the reaction of cinnamic acid with soil for 18 hours resulted in the significant elimination of its bioactivity. However, the initial phytotxicity after soil incorporation with mulches may coincide with the early, critical stage of weed emergence and establishment. Different results have been obtained by Krogmeier and Bremner (1989) who found that the negative effect of plant residues on crop yields was not due to phenolic acids from residues, as there was no effect found on seed germination in the soil.

Among the investigated phenolic acids, two compounds: protocatechuic and chlorogenic acid, were not detected in any soil samples (the control soil and the mulched soil), neither in technology I or II. An explanation of this phenomenon has been by E $\mathrm{n} g$ e 1 $\mathrm{h}$ a rd t et al. (1976) who found rapid degradation of protocatechuic acid by some soil bacteria.

The influence of weather conditions (decade temperature and rainfall) on the amount of phenolic compounds in soil and primary weed infestation was very important in our experiment. According to the $K$ coefficient, hydrothermic conditions during the period of April-May in 2002 and 2004 were not as wet as those observed in a similar period in the 2003 season. Perhaps, the high level of rainfall occurring during these months in the 2003 vegetative season promoted higher degradation of phenolics. S è n e et al. (2000) also found different concentrations of phenolic acids in soil, depending on the vegetative season. On the contrary, the primary weed infestation level was much higher in 2002, when the higher level of phenolic compounds in soil was noted. According to S t u p n i c k a R o dzy nki e w i c z et al. (2004), a low reduction in the number of selected weed species after mulch incorporation into soil is promoted by wet and cool weather. A less inhibitory effect of the incorporated mulches on weeds was observed in technology I, when the donorplants developed lower amounts of biomass, comparing to technology II. In technology II the effect of the plant mulches was more effective, as the weeds in the maize interrows were initially shadowed by the grow- 
ing donor plants and then inhibited by the mulch incorporated with soil. Also the weather conditions for the donor plants, occurring during the mulching period in technology II, were more favorable, because the plants grew in a higher temperature.

Generally, the plant mulches, especially oats, buckwheat and mustard, were more inhibitory against monocotyledonous weeds. Buckwheat is well known for its inhibitory, allelopathic effect against quackgrass (Elymus repens L.) (Golis z et al. 2002). B i a ly et al. (1990), who studied allelopathic potential of mustard against wheat, found its usefulness in weed control.

\section{CONCLUSIONS}

The level of phenolic compounds in soil and the primary weed infestation level varied largely between the vegetative seasons for both technologies of mulch incorporation with soil. The level of weed infestation in maize was weakly correlated with the amounts of phenolic compounds in soil, but both these phenomena were influenced by weather conditions. In the wet conditions during April-June, phenolic compounds degraded more rapidly and a stimulation of weed growth was observed. The mulches used in technology II, when the donor plants were incorporated with soil in the maize interrows after a month of growth, inhibited primary infestation more efficiently, particularly for monocotyledonous weeds. The hypotheses tested in our study were confirmed: 1) an increase of phenolic acids content in soil, after mulch incorporation, was found; 2) a decrease of primary weed infestation in maize, after mulch incorporation, was found; 3) a decrease of primary weed infestation is not always correlated with increased amounts of phenolic compounds in soil. Besides, amounts of phenolic compounds in soil depend largely on both hydrothermal conditions occurring in each vegetative season and the technology of mulch incorporation with soil. Moreover, amounts of phenolic compounds in soil not always differ significantly from control plots. All these restrictions allow us to offer only a partial explanation of the influence of mulches on primary weed infestation in maize.

\section{Acknowledgments}

This work was financially supported by the State Committee for Scientific Research (KBN), grant number 6 P06R 01021.

\section{REFERENCES}

Bhow mik P. C., Inderjit, 2003. Challenges and opportunities in implementing allelopathy for natural weed management. Crop Prot. 22: 661-671.

Bialy Z., Oleszek W., Lewis J. Fenwick G. R., 1990. Allelopathic potential of glucosinolates (mustard oil glycosides) and their degradation products against wheat. Plant Soil, 129: 277-281.

Blum U., 1998. Effects of microbial utilization of phenolic acids and their phenolic acid breakdown products on allelopathic interactions. J. Chem. Ecol. 24: 685-708.

Chou C. H., Patrick Z. A., 1976. Identification and phytotoxic activity of compounds produced during decomposition of corn and rye residues in soil. J. Chem. Ecol. 2: 369-387.

Dhima K.V., Vasilakoglou I.B., Eleftherohorinos I. G., Lithourgidis A. S., 2006. Allelopathic potential of winter cereals and their cover crop mulch effect on grass weed suppression and corn development. Crop Sci. 46: 345-352.

Engelhardt G., Wallnöfer P. R., Rast H. G., Fied1er F., 1976. Metabolism of $o$-phthalic acid by different gram-negative and gram-positive soil bacteria. Arch. Microbiol. 109: 109-114.

Golisz A., Ciarka D., Gawroński S. W., 2002. Allelopathic activity of buckwheat - Fagopyrum esculentum Moench. In: Proceedings of the III Word Congress on Allelopathy. Y. Fujii, S. Hidarate, H. Araya (ed.), Tsukuba, Japan: 161.

Hochol T., Stupnicka-Rodzynkiewicz E., Lepiarczyk A., Hura T., Dubert F., Stoklosa A., 2004. The influence of date of selected plant species mulch incorporation into the soil on their weed infestation limiting effect. In: Annales AFPP, Proceedings of the XII International Conference on Weed Biology, Dijon, France: 187-194.

Hura T., Dubert F., Dąbkowska T., Stupnicka-Rodzynkiewicz E., Stokłosa A., Lepiarczyk A., 2006. Quantitative analysis of phenolics in selected crop species and biological activity of these compounds evaluated by sensitivity of Echinochloa crus-galli. Acta Physiol. Plant. 28: 537-545.

Inderjit K. M., Foy C. L., 2001. On the significance of field studies in allelopathy. Weed Technol. 15: 792-797.

Inderjit, Keating K. I., 1999. Allelopathy: principles, procedures, processes, and promises for biological control. Adv. Agron. 67: 141-231.

Inderjit, 1996. Plant phenolics in allelopathy. Bot. Rev. 62: 186-202.

Iqbal Z., Hiradate S., Noda A., Fujii Y., 2003. Allelopathic activity of buckwheat: isolation and characterization of phenolics. Weed Sci. 51: 657-662.

Kefeli V. I., Kalevitch M. V., Borsari B., 2003. Phenolic cycle in plants and environment. J. Cell Mol. Biol. 2: $13-18$. 
Kobayashi K., 2004. Factors affecting phytotoxic activity of allelochemicals in soil. Weed Biol. Manag. 4: 1-7.

Krogmeier M. J., Bremner J. M., 1989. Effects of phenolic acids on seed germination and seedling growth in soil. Biol. Fertil. Soils, 8: 116-122.

Macías F. A., Molinillo J. M. G., Varela, R. M., Galindo, J. C. G., 2007. Allelopathy - a natural alternative for weed control. Pest Manag. Sci. 63: 327-348.

Narwal S. S., 1999. Allelopathy in ecological agriculture. In: Allelopathy in Ecological Agriculture and Forestry. S. S. Narwal et al. (ed.), Dordrecht, Netherlands: Kluwer Academic Publishers: 11-32.

Ohno T., 2001. Oxidation of phenolic acid derivatives by soil and its relevance to allelopathic activity. J. Environ. Qual. 30: 1631-1635.

Ostrowska D., Cieśliński M., Gozdowski D., Owczarek E., 2007. Plant density of spring oilseed rape and its productivity. Fragm. Agron. 94: 217-226.

Ozolinčius R., Stakènas V., 2001. Effects of air pollution and droughts on forest condition in Lithuania. Biologija, 2: 99-101.

Sène M., Doré T., Pellissier F., 2000. Effect of phenolic acids in soil under and between rows of a prior sorghum (Sorghum bicolor) crop on germination, emergence and seedling growth of peanut (Arachis hypogea). J. Chem. Ecol. 26: 625-637.

Singleton V. L., Rossi J. A., 1965. Colorimetry of total phenolics with phosphomolybdic-phosphotungstic acid reagents. American J. Enol. Viticult. 16: 144-158.

Souto X. C., Chiapusio G., Pellissier F., 1998. Soil microorganisms and phenolics: their implication in spruce natural regeneration failure. In: Forest Ecosystems and Biodiversity, Proceedings of the IUFRO Kyoji S. (ed.), Kyoto, Japan: Kluwer Academic Publishers: 301-307.

Souto X. C., Chiapusio G., Pellissier F., 2000. Relationship between phenolics and soil microorganisms in spruce forests: significance for natural regeneration. J. Chem. Ecol. 26: 2025-2034.

StatSoft Inc., 2005 STATISTICA (data analysis software system), version 7.1. www.statsoft.com

Stupnicka-Rodzynkiewicz E., Hochol T., Lepiarczyk A., Hura T., Dubert F., Stoklosa A., 2004. The influence of weather course on limiting weed infestation with mulch from selected plant species. In: Annales AFPP, Proceedings of the XII International Conference on Weed Biology, Dijon, France: 179-186.

Szajdak L., Życińska-Bałoniak I., 1994. Phenolic acids in brown soils under continuous cropping of rye and crop rotation. Polish J. Soil Sci. 27: 113-121.

Weston L. A., Duke S. O., 2003. Weed and crop allelopathy. Crit. Rev. Plant Sci. 22: 367-389.
Whitehead D. C., Dibb H., Hartley R. D., 1982. Phenolic compounds in soil as influenced by the growth of different plant species. J. Appl. Ecol. 19: 579-588.

Wu H., Haig T., Pratley J., Lemerle D., An M., 2000. Distribution and exudation of allelochemicals in wheat Triticum aestivum. J. Chem. Ecol. 26: 2141-2154.

Xuan T. D., Tawata S., Khanh T. D., Chung I. M., 2005. Decomposition of allelopathic plants in soil. J. Agron. Crop Sci. 191: 162-171.

\section{Wpływ mulczów na zawartość związków fenolowych w glebie i zachwaszczenie pierwotne kukurydzy}

\section{Streszczenie}

W uprawie kukurydzy stwierdzono wzrost zawartości związków fenolowych i wybranych kwasów fenolowych $\mathrm{w}$ glebie po wprowadzeniu do niej mulczu z: gorczycy białej, gryki, jęczmienia jarego, owsa i żyta. Najwyższą zawartość związków fenolowych stwierdzono w glebie z mulczem z owsa (o $20 \%$ więcej, niż w glebie kontrolnej). Najwyższą zawartość wybranych kwasów fenolowych stwierdzono w glebie z mulczami z owsa i żyta. W glebie z mulczami najczęściej stwierdzano kwas ferulowy. Jednocześnie w żadnej glebie (kontrolnej i z mulczami) nie stwierdzono występowania kwasów fenolowych: protokatechowego i chlorogenowego. Równocześnie na tych samych poletkach z mulczami stwierdzono zmniejszenie zachwaszczenia pierwotnego kukurydzy, wyraźne zwłaszcza z mulczem z owsa, jęczmienia jarego i gorczycy białej. Zastosowane mulcze bardziej ograniczały wzrost chwastów jednoliściennych.

Wyraźne zmniejszenie ilości związków fenolowych w glebie oraz zwiększenie zachwaszczenia pierwotnego kukurydzy obserwowano w okresie zwiększania ilości opadów i wilgotnej pogody. 